\title{
Middle Miocene (Badenian) macroinvertebrates from Pécs-Danitzpuszta (Mecsek Mts, SW Hungary)
}

\author{
Dulai, Alfréd ${ }^{1}$, Henn, Tamás², SeBE, Krisztina ${ }^{3}$ \\ ${ }^{1}$ Hungarian Natural History Museum, Department of Palaeontology and Geology, 1083 Budapest, Ludovika tér 2-6, Hungary; \\ dulai.alfred@nhmus.hu \\ ${ }^{2}$ Local History and Natural History Museum Collection - Komló, 7300 Komló, Városház tér 1., Hungary; henn.tomi@ gmail.com \\ ${ }^{3}$ University of Pécs, Department of Geology and Meteorology, 7624 Pécs, Ifjúság útja 6., Hungary; sebe @ gamma.ttk.pte.hu
}

\begin{abstract}
Középsố miocén (badeni) makrogerinctelenek Pécs-Danitzpusztáról
Összefoglalás

Badeni normál tengeri üledékekből származó makrogerincteleneket - korallokat és puhatestúeket - vizsgáltunk a pécs-danitzpusztai homokbányából. A korallok a felső miocén, pannon-tavi homokban áthalmozva fordulnak elő, és a Lajtai Formáció középső badeni Pécsszabolcsi vagy felső badeni Rákosi Mészkő Tagozatából származhatnak. Az azonosított hét taxon szubtrópusi éghajlatra és önálló korallzátonyok hiányára utal. A puhatestûek a felső badeni Badeni Formáció Szilágyi Agyagmárga Tagozatának és a Lajtai Formáció Rákosi Mészkő Tagozatának szálban álló rétegeiből származnak. A kagylók uralta fauna az adott időszak Középső-Paratethysre jellemző fajait tartalmazza.
\end{abstract}

Kulcsszavak: Mecsek, badeni, korall, puhatestú, lajtamészkó

\begin{abstract}
This paper examines Badenian (middle Miocene) macroinvertebrates - corals and molluscs - from the Pécs-Danitzpuszta sand pit (Mecsek Mts, SW Hungary) in order to extend our knowledge on Miocene normal marine deposits of the Mecsek region. Corals occur reworked in the upper Miocene sand that was deposited in the brackish Lake Pannon, and presumably originate either from the middle Badenian Pécsszabolcs or the upper Badenian Rákos Member of the Lajta Formation. A total of seven taxa were identified. These taxa suggest subtropical conditions and a lack of coral reefs in the Badenian. Molluscs were found in situ in the upper Badenian Szilágy Clay Marl Member of the Baden Formation and the Rákos Member of the Lajta Formation. They dominantly consist of bivalves and represent benthic assemblages typical of the middle Miocene Central Paratethys.
\end{abstract}

Keywords: Mecsek Mts., Badenian, coral, mollusc, Leitha limestone

\section{Introduction}

Miocene sedimentary formations are common around the Mecsek Mts. (HÁmor 1970, ChiKÁn 1991, Sebe et al. 2015). Among these, deposits accumulated under normal marine conditions occur only in the Badenian (corresponding to the Langhian and Serravallian standard stages). At some sites the various bioclastic limestones, calcareous sands and silts contain abundant invertebrate faunas. Despite this, the number of papers describing Badenian invertebrates from the Mecsek area is rather limited. StRAUSZ (1923, 1928) studied the mollusc fauna and the Miocene stratigraphy at Mecsekjánosi (now part of Komló), Szopók (later Mecsekfalu, now part of Komló) and Mecsekpölöske.
Later, two voluminous monographs dealt with the mollusc fauna of Hidas (CSEPREGHY-MEZNERICS 1950) and the Eastern Mecsek (BoHn-Havas 1973). Recently, the Muricidae gastropods were studied in detail from Orfú-Tekeres, Mecsekpölöske, Kisbattyán, Hidas and Hosszúhetény by KoVÁCS (2020).

As for the Miocene corals, many studies have been published about these in Hungary (HEGEDÛ́s 1970, HegEDÚs \& JANKOVICH 1972, KoPeK 1954, OOSTERBAAN 1990, ReUSS 1872, SchOlZ 1970); however, only very few mention sites from the Mecsek. STRAUSZ (1923, 1928, 1942) reported coral fragments from the Leitha limestone north of Mecsekjánosi (now part of Komló), patch reefs in the same horizon near Mecsekpölöske, and coral-bearing clay near Bodolyabér, but 
provided neither taxonomic details nor illustrations. FöLDI et al. (1967) listed "Anthozoa remains" in the faunal list of the Tekeres Schlieren south of Hosszúhetény, without any further details, while HÁmOR (1970) mentioned solitary corals from the upper part of the same unit in the borehole Komló-XLI, drilled between Komló and Mánfa. SoósNÉ (2013) described colonial corals from Mecsekpölöske and included photos as well. She identified the colonies as belonging to hexacorals and stated that they needed precise taxonomic classification. The summary work of FôZY \& SZENTE (2014) writes that "fine corals can be found in the Mecsek around Pécsszabolcs". The most characteristic forms of the Hungarian localities are Tarbellastraea, Porites and Montastraea (OOSTERBAAN 1990). However, a detailed examination and description of the corals of the Mecsek region is lacking.

The Pécs-Danitzpuszta sand pit, which exposes upper Miocene Lake Pannon brackish-water calcareous marls and sands, is a famous and well-known fossil locality for upper Miocene (Pannonian) molluscs and diverse vertebrate remains (SZABÓ et al. 2021). The latter include redeposited middle Miocene (mostly Badenian) bones and teeth of marine fishes and mammals, but until now Badenian marine molluscs have not been reported from here. A few dozens of scleractinian corals have been found in the last few years in the sand pit by private collectors. These corals were redeposited into the upper Miocene sands. The artificial trench excavated at the sand pit in September 2018 exposed some upper Badenian sediments in situ, at the lower part of the $220 \mathrm{~m}$ thick section (SEBE et al. 2021). These Badenian layers yielded uncommon and not very diverse, poorly preserved mollusc fauna.

This short paper reports on Badenian molluscs and corals to extend our knowledge on Miocene normal marine deposits of the Mecsek region.

\section{Material and methods}

The studied corals were collected from the upper Miocene sands of the sand pit. The sand quarried in the pit was deposited in the brackish Lake Pannon. The examined specimens are parts of collections of the Mining and Geological Survey of Hungary (Budapest, uninventoried material), of the Local History and Natural History Museum Collection in Komló, and of the private collection of Ferenc CSERPÁK in Budapest (uninventoried material). In total, 37 coral specimens were examined. Analysis of the specimens was carried out using a stereo microscope (Leica Zoom 2000) and a digital caliper. Taxonomic assignment was based on macrostructural features, e.g., colony shape, calice size and shape, calicular wall, septum development, morphology of the columella and coenosteum characteristics.

Badenian molluscs were collected from in situ Badenian rocks in the exploratory trench at Pécs-Danitzpuszta. They come from the massive, crumbly, sandy limestone of layer 71 and from the thick-bedded calcareous marls of layer 72 (for the sedimentary succession see SEBE et al. 2021). The studied specimens are housed in the palaeontological collection of the Hungarian Natural History Museum, Budapest (inventory numbers INV 2021.62-2021.75).

\section{Results \\ Corals}

All examined specimens are fragments of coral colonies (Figure 1). The size of the fragments varies between 0.8 and 8.7 centimetres. Macroscopic features were sufficient to identify the specimens at the genus level, since the diagnostic characters had been preserved on all specimens. The 37 specimens were assigned into seven taxa. (Table I.). Basic morphometric data are presented in Table II.

Most of the specimens are colony fragments and the deeper regions of calices are filled with sand. On the surface of the largest specimen, Tarbellastrea reussiana, few typical borings of the mytilid Lithophaga sp. (Figure 1) were also observed.

\section{Molluscs}

Altogether 45 mollusc specimens were identified (layer 71: 25; layer 72: 20, Table III). With the exception of the calcite-shelled ostreids, all of the specimens are external or internal moulds (Figure 2). Nearly all of the molluscs belong to bivalves (44); gastropods are represented by a single Rissoa specimen.

All members of the fauna are typical in the middle Miocene benthic assemblages of the Central Paratethys, also including the Mecsek area (CSEPREGHY-MEZNERICS 1950, BoHN-HAVAS 1973). In the absence of pectinids, this mollusc fauna is not suitable for a more accurate biostratigraphic assignment, as the identified species have relatively long stratigraphic ranges.

\section{Discussion}

As appropriate circumstances for corals (e.g., normal salinity and sufficiently warm sea water) were present in the area only in the Badenian (FóZY \& SZENTE 2014, SEBE et al. 2019), it is evident that the corals of Pécs-Danitzpuszta originate from Badenian rocks. The potential source rocks are the littoral Leitha limestones: either the middle Badenian Pécsszabolcs ("lower Leitha limestone") or the upper Badenian Rákos ("upper Leitha limestone") Member of the Lajta Formation. The lower Pécsvárad Member crops out north of the sand pit (HÁmoR et al. 1966), while the upper Rákos Member is identified in the exploratory trench in the sand pit, just below Sarmatian rocks (SEBE et al. 2021). Since no corals have been reported from either of the two stratigraphic units yet, the question of provenance of the corals that were found in the sand pit remains open. Still, the presence of corals is a hitherto unreported feature of Badenian deposits in the area. 

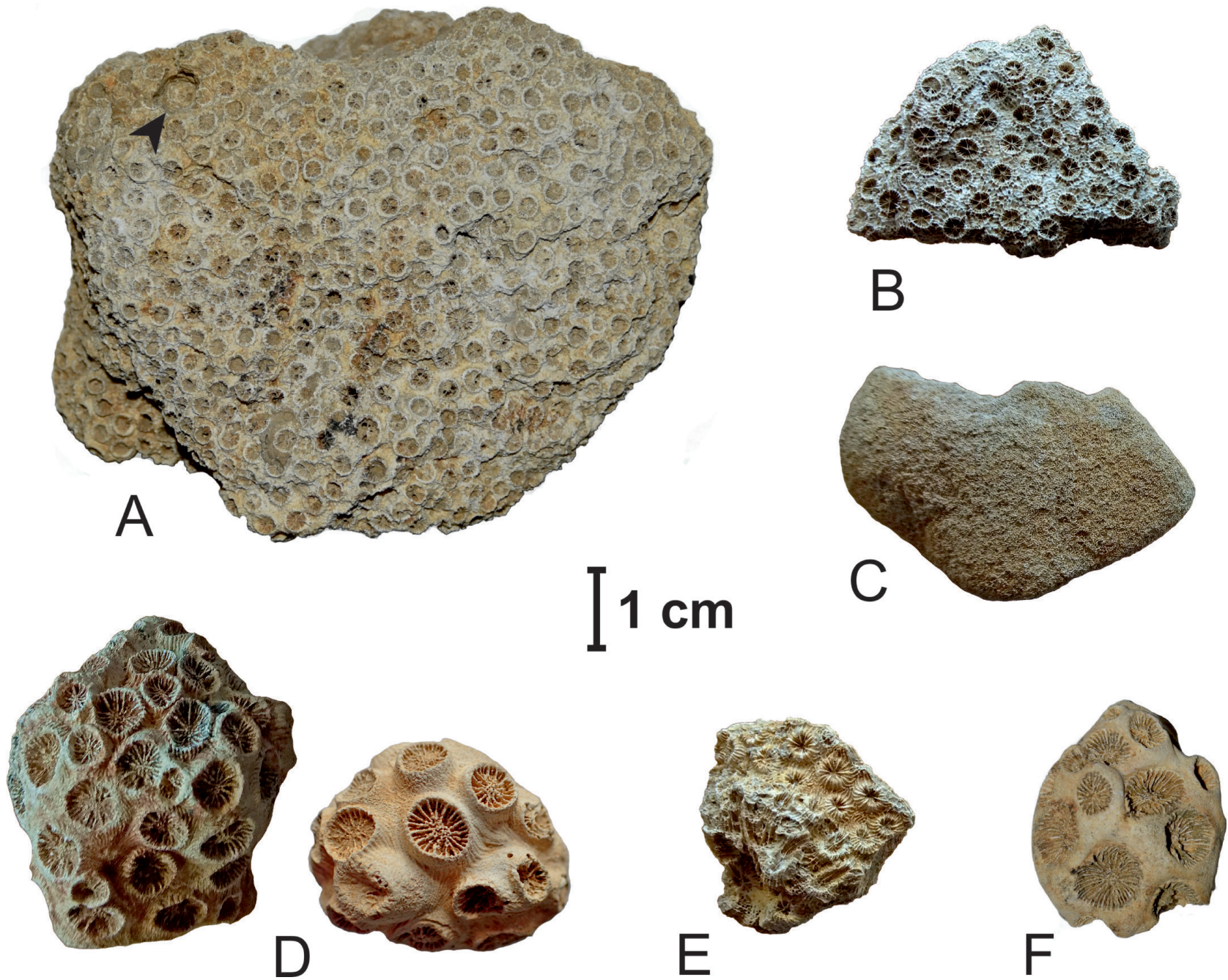

Figure 1. Scleractinian corals from Pécs-Danitzpuszta

A - Tarbellastrea reussiana MiLne-Edwards \& Haime, 1850 (Local History and Natural History Museum Collection, Komló) with Lithophaga boring (arrow), B - Tarbellastrea tenera Reuss, 1847 (Private collection of Ferenc CSERPÁK, Budapest), C - Porites collegniana Michelin, 1842 (Collection of the Mining and Geological Survey of Hungary, Budapest), D - cf. Cladangia conferta Reuss, 1847 (Private collection of Ferenc CserpáK, Budapest), E - cf. Plesiastrea sp. (Collection of the Mining and Geological Survey of Hungary, Budapest), F - cf. Astroides subirregularis OsASCO, 1897 (Local History and Natural History Museum Collection, Komló)

1. ábra. Telepes kökorallok (Scleractinia) Pécs-Danitzpusztáról

A - Tarbellastrea reussiana MILNE-EDWARDS \& HAIME, 1850 (Komlói Helytörténeti és Természettudományi Gyüjtemény) Lithophaga fúrás nyomával (nyíl), B - Tarbellastrea tenera REUSS, 1847 (CSERPÁK Ferenc magángyüjteménye, Budapest), C - Porites collegniana MICHELIN, 1842 (Magyar Bányászatiés Földtani Szolgálat gyüjteménye, Budapest), D - cf. Cladangia conferta ReusS, 1847 (CSERPÁK Ferenc magángyüjteménye, Budapest), E - cf. Plesiastrea sp. (Magyar Bányászati és Földtani Szolgálat gyüjteménye, Budapest), F - cf. Astroides subirregularis OSASCO, 1897 (Komlói Helytörténeti és Természettudományi Gyüjtemény)

Table I. The list of identified taxa in the three collections

I. táblázat. A három gyüjteményben azonosított telepes kökorallok (Scleractinia) listája

Collection of the Mining and Geological Survey of Hungary (Budapest):

cf. Astroides subirregularis Osasco, 1897

cf. Plesiastrea sp.

Porites collegniana MICHELIN, 1842

Tarbellastraea cf. reussiana MILNE-EDWARDS \& HAIME, 1850

Tarbellastraea cf. tenera REUSS, 1847

cf. Tarbellastraea sp.

(1 specimen)

(1)

(1)

(20)

(1)

Local History and Natural History Museum Collection (Komló):

cf. Astroides subirregularis OSASCO, 1897

Tarbellastraea reussiana MILNE-EDWARDS \& HAIME, 1850

(1) (INV 2019.9.1.)

(2) (INV 2019.10.1., 2021.1.1.)

Private collection of FERENC CSERPÁK (Budapest):

cf. Astroides subirregularis OSASCO, 1897

cf. Cladangia conferta REUSS, 1847

Tarbellastraea reussiana MILNE-EDWARDS \& HAIME, 1850

Tarbellastraea cf. reussiana MILNE-EDWARDS \& HAIME, 1850

Tarbellastraea tenera REUSS, 1847 
Table II. Species list and summary of the main diagnostic characters used to identify the specimens

II. táblázat. A telepes kökorallok (Scleractinia)fajlistája és a példányok azonositásához használt fontosabb diagnosztikus tulajdonságok

\begin{tabular}{lcccccc}
\hline Species & Colony & $\mathrm{CD}(\mathrm{mm})$ & No. septa & No. cycles & Coenosteum Columella \\
\hline Astroides subirregularis & $\mathrm{M}$ & $3.0-8.5$ & $28-32$ & 4 & $\mathrm{Sm}$ & $\mathrm{S}$ \\
Cladangia conferta & $\mathrm{M}, \mathrm{B}$ & $4.5-6.5$ & $34-36$ & 4 & $\mathrm{Cos}$ & $\mathrm{S}-\mathrm{P}$ \\
Plesiastrea sp. & $\mathrm{M}$ & $2.0-4.5$ & $20-24$ & 3 & $\mathrm{Cos}$ & - \\
Porites collegniana & $\mathrm{E}$ & $0.6-1.1$ & $12-20$ & 3 & $\mathrm{Sp}$ & $\mathrm{T}$ \\
Tarbellastraea reussiana & $\mathrm{M}$ & $1.0-3.1$ & $24-30(?)$ & $3-(4)$ & $\mathrm{Cos}$ & $\mathrm{T}$ \\
Tarbellastraea sp. & $\mathrm{M}$ & $1.0-2.8$ & $22-28(?)$ & $3-(4)$ & Cos & ?T \\
Tarbellastraea tenera & $\mathrm{M}$ & $1.6-2.2$ & 24 & 3 & Cos & $\mathrm{T}$ \\
\hline
\end{tabular}

Colony: $\mathrm{B}=$ branching, $\mathrm{E}=$ encrusting, $\mathrm{M}=$ massive $. \mathrm{CD}=$ calicular diameter. Coenosteum: $\mathrm{Cos}=$ costae present, $\mathrm{Sm}=$ smooth, $\mathrm{Sp}=$ spongy. Columella: $\mathrm{P}=$ papillose, $\mathrm{S}=$ spongy, $\mathrm{T}=$ trabecular

Telelepforma: $B=$ ágas, $E=$ kéregszerü, $M=$ gumószerü. $C D=$ kehelyátmérö. Köztesváz: $C o s=$ bordázott, $S m=$ sima, $S p=$ szivacsos.

Kolumella: $P=$ szemölcsszerü, $S=$ szivacsos, $T=$ trabekuláris

The low $(<10)$ number of identified species suggests less favourable circumstances for corals (KIESSLING 2001, PANDOLFI 2011, SCHOLZ 1970). Due to the subtropical rather than tropical climate of the Central Paratethys, typical coral reefs did not form in the Mecsek region, similarly to other localities in the northern part of Hungary and Austria (OOSTERBAAN 1990, PILLER \& KLEEMANN 1991). It is likely that the Badenian corals of the Mecsek may have lived in small scattered banks or formed patch reefs and coral carpets (see RIEGL \& PILLER 2000). Although no completely intact colony was found among the specimens, the preservation of the corals was very good. In some cases Lithophaga sp. borings were also observed, similarly to corals described by PILLER \& KLEEMANN (1991).

Molluscs provide information on the Lajta Formation as well. The mollusc fauna of the Leitha limestone is less diverse, but more numerous than that of the underlying Szilágy Clay Marl: only four bivalve taxa are present, with a strong dominance of Cubitostrea digitalina (21 out of 25 specimens). Ostreids are represented by thin-shelled and predominantly small-sized specimens. Cubitostrea digitalina is an epibenthic shallow-water suspension feeder, attached to hard surfaces of the sea bottoms. The small size of the specimens may refer to unfavourable environmental conditions for Cubitostrea. Venus multilamella and Myrtea spinifera belong to vagile infauna and they prefer soft muddy bottoms.
The less numerous mollusc fauna of the Szilágy Clay Marl is much more diverse (10 taxa; one gastropod and nine bivalve species), and the most common species, $\mathrm{Ve}$ nus (Ventricoloidea) multilamella is less dominant $(6 / 20$ specimens). The single gastropod, Rissoa, is of a small sized herbivorous taxon, living mostly on brown algae. All bivalve species belong to the inbenthos and they lived freely in muddy or fine sandy substrate, indicating a several tens of metres deep, low-energy depositional environment. Some of the bivalves (Myrtea, Acanthocardia, Pitar, and Crassatina) are suspension feeders, whereas others (Nuculana, Tellina, and Gastrana) are detritus feeders. Most of the bivalve external moulds show evidence of bioerosion trace fossils within the dissolved original shell materials.

\section{Conclusions}

This is the first study where Miocene coral species from the Mecsek region are identified. The relatively low number of species suggests subtropical conditions and a lack of typical coral reefs in the Badenian. Molluscs indicate similar ecological conditions and a decreasing water depth in the late Badenian.

Table III. The list of identified taxa in the studied mollusc material

III. táblázat. A vizsgált anyagban azonositott puhatestü taxonok listája

Layer 71 (Rákos Member of Lajta Formation; SEBE et al. 2021):

Cubitostrea digitalina (EICHWALD, 1830)

Pectinidae indet.

Myrtea spinifera (MONTAGU, 1803)

(21 specimens) (INV 2021.62.)

Venus (Ventricoloidea) multilamella (LAMARCK, 1818)

(1) (INV 2021.63.)

(1) (INV 2021.64.)

(2) (INV 2021.65.)

Layer 72 (Szilágy Clay Marl Member of the Baden Formation; SEBE et al. 2021):

Rissoa turricula EICHWALD, 1830

(1) (INV 2021.66.)

Nuculana (Saccella) fragilis (CHEMNITZ, 1784)

Cubitostrea digitalina (EICHWALD, 1830)

Venus (Ventricoloidea) multilamella (LAMARCK, 1818)

Tellina? sp.

(1) (INV 2021.67.)

(2) (INV 2021.68.)

(6) (INV 2021.69.)

Myrtea spinifera (MONTAGU, 1803)

(1) (INV 2021.70.)

Acanthocardia? sp.

(1) (INV 2021.71.)

Pitar rudis (PoLI, 1795)

(2) (INV 2021.72.)

Crassatina moravica (HöRNES, 1870)

(2) (INV 2021.73.)

Gastrana fragilis (LINNAEUS, 1758)

(1) (INV 2021.75.) 

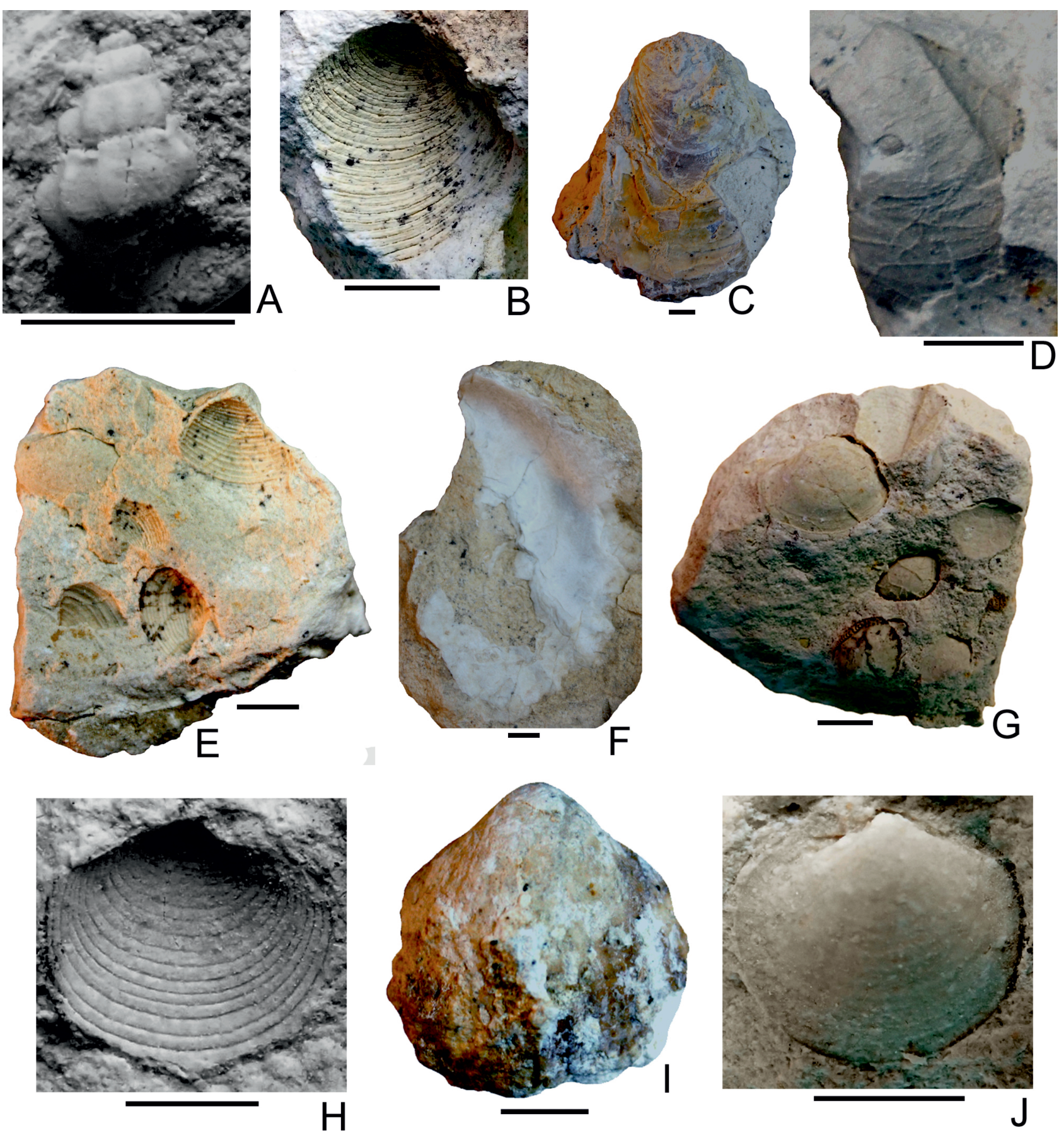

Figure 2. Molluscs from the Badenian layers of the Pécs-Danitzpuszta sand pit

$\mathrm{A}=$ Rissoa turricula EICHWALD, 1830, B = Venus (Ventricoloidea) multilamella $($ LAMARCK, 1818), C = Cubitostrea digitalina $($ EICHWALD, 1830), D = Crassatina moravica $($ HöRnes, 1870), $\mathrm{E}=$ Tellina? sp., Venus (Ventricoloidea) multilamella (LAMARCK, 1818), $\mathrm{F}=$ Cubitostrea digitalina (EICHWALD, 1830), G = Pitar rudis (Poli, 1795), Nuculana (Saccella) fragilis (ChemnitZ, 1784), $\mathrm{H}=$ Myrtea spinifera (MonTAGU, 1803), $\mathrm{I}=$ Acanthocardia? sp., $\mathrm{J}=$ Myrtea spinifera (MonTAGU, 1803). Scale $=5 \mathrm{~mm}$

2. ábra. A pécs-danitzpusztai homokfejtő badeni rétegeinek puhatestü-maradványai

$A=$ Rissoa turricula EICHWALD, 1830, B = Venus (Ventricoloidea) multilamella (LAMARCK, 1818), C = Cubitostrea digitalina (EICHWALD, 1830), D =Crassatina moravica (HöRNES, 1870), E= Tellina? sp., Venus (Ventricoloidea) multilamella (LAMARCK, 1818), F= Cubitostrea digitalina (EICHWALD, 1830), G = Pitar rudis (POLI, 1795), Nuculana (Saccella) fragilis (CHEMNITZ, 1784), $H=$ Myrtea spinifera (MONTAGU, 1803), $I=$ Acanthocardia? sp., $J=$ Myrtea spinifera (MONTAGU, 1803). Méretarány $=5 \mathrm{~mm}$

\section{Acknowledgements}

Corals were collected by two enthusiastic private collectors, Ferenc CSERPÁK and László KANIZSAI. Molluscs were collected by Ildikó SELMECZI, Richárd AlBrecht, Krisztina SEBE and Keve LACZIK. We thank the curators of the institutional collections and the private collectors for helping us during the investigations. Our own collecting activities were supported by the OTKA/NKFIH (Hungarian National Research, Development and Innovation Office) project 116618. We thank Ildikó SELMECZI (Mining and Geological Survey of Hungary) for discussions. We are grateful to the chief editor, Orsolya SzTANó and two reviewers, Rosemarie BARONSZABÓ and István SzENTE for their helpful suggestions. 


\section{References - Irodalom}

Bohn-Havas M. 1973: A Keleti-Mecsek torton Mollusca faunája. (Tortonische Molluskenfauna des Östlichen Mecsek-Gebirges). A Magyar Állami Földtani Intézet Évkönyve 53/4, 951-1161.

CHIKÁN G. 1991: A Nyugati-Mecsek kainozoós képződményei. (Die Känozoischen Ablagerungen des westlichen Mecsekgebirges.) A Magyar Állami Földtani Intézet Évkönyve 72, 1-281.

CSEPREghY-Meznerics I. 1950: A hidasi (Baranya m.) tortonai fauna. [Die Tortonische fauna von Hidas (kom. Baranya, Ungarn)]. A Magyar Állami Földtani Intézet Évkönyve 39/2, 1-115.

Földi M., Nagy E., Hámor G., HetéNYi R. 1967: Magyarázó Magyarország földtani térképéhez. 10 000-es sorozat. Hosszúhetény. [Explanations to the geological maps of Hungary. Scale 1:10 000. Hosszúhetény.] - Magyar Állami Földtani Intézet, Budapest, 35 p.

FöZY, I. \& SZENTE, I. 2014: Fossils of the Carpathian Region. - Indiana University Press, Bloomington and Indianapolis, 483 p.

HÁmor G. 1970: A Kelet-Mecseki miocén. (Das Miozän des östlichen Mecsek-Gebirges.) - A Magyar Állami Földtani Intézet Évkönyve 53/1, 1-483.

HÁMor G., NAGY E., FöLdI M. 1966: Magyarország földtani térképe, 10000-es sorozat, Pécs-Meszes [Geological maps of Hungary, 1:10000 scale series, Pécs-Meszes]. - Magyar Állami Földtani Intézet, Budapest.

HEGEdưs Gy. 1970: Tortonai korallok Herendről. (Coralliaires tortoniens de Herend.) - Földtani Közlöny 100, $185-191$.

HEGEdús Gy. \& JANKOVICH I. 1972: Badenien korallzátony Márkházáról. - A Magyar Állami Földtani Intézet Évi Jelentése 1970-ról, 39_ 53.

KIESSLING, W. 2001: Paleoclimatic significance of Phanerozoic reefs. - Geology 29/8, 751-754. https://doi.org/10.1130/00917613(2001)029\%3C0751:PSOPR\%3E2.0.CO;2

KOPEK G. 1954: Északmagyarországi miocén korallok. - A Magyar Állami Földtani Intézet Évkönyve 42/1,: 3-33.

KovÁcs, Z. 2020: New Muricidae (Neogastropoda) faunas from the Middle Miocene of Hungary. - Földtani Közlöny 150/3, 449-468. https://doi.org/10.23928/foldt.kozl.2020.150.3.449

OosterbaAn, A. F. F. 1990: Notes on a collection of Badenian (Middle Miocene) corals from Hungary in the National Museum of Natural History at Leiden (The Netherlands). - Contributions to Tertiary and Quaternary Geology 27/1, 3-15.

Pandolfi, J. M. 2011: The Paleoecology of Coral Reefs. - In: Dubinsky, Z. \& Stambler, N. (eds): Coral Reefs: An Ecosystem in Transition. Springer, Dordrecht, 552 p. https://doi.org/10.1007/978-94-007-0114-4_2

Piller, W. E. \& KleEmann, K. 1991: Middle Miocene reefs and related facies in eastern Austria. I. Vienna Basin. - Excursion Guidebook $6^{\text {th }}$ International Symposium on Fossil Cnidaria, Münster, 1-28.

Reuss, A. E. 1872: Die fossilien Korallen des österreich-ungarischen Miocäns. - Denkschriften der Kaiserlichen Akademie der Wissenschaften. Mathematisch-Naturwissenschaflichen Klasse 31/1, 197-270.

RIEGL, B. \& PILLER, W. E. 2000: Reefs and coral carpets in the Miocene Paratethys (Badenian, Leitha Limestone, Austria). - Proceedings $9^{\text {th }}$ International Coral Reef Symposium, Bali, Indonesia 23-27 October 2000.

Scholz G. 1970: A visegrádi Fekete-hegy tortonai korall faunája. (The Tortonian coral fauna of Fekete hill at Visegrád.) - Földtani Közlöny 100, 192-206.

Sebe, K., Csillag, G., Dulai, A., Gasparik, M., Magyar, I., Selmeczi, I., Szabó, M., Sztanó, O. \& Szuromi-Korecz, A. 2015: Neogene stratigraphy in the Mecsek region. - In: Bartha, I. R., Kriván, Á., Magyar, I. \& Sebe, K. (eds): Neogene of the Paratethyan Region. $6^{\text {th }}$ Workshop on the Neogene of Central and South-Eastern Europe. An RCMNS Interim Colloquium. Programme, Abstracts, Field Trip Guidebook, Hungarian Geological Society, Budapest, 102-124.

Sebe, K., Selmeczi, I., Szuromi-Korecz, A., Hably, L., Kovács, Á. \& Benkó, Zs. 2019: Miocene syn-rift lacustrine sediments in the Mecsek Mts. (SW Hungary). - Swiss Journal of Geosciences 112, 83-100. https://doi.org/10.1007/s00015-018-0336-1

Sebe K., Konrád Gy., SzTanó O. 2021: An exceptional surface occurrence: the middle to upper Miocene succession of PécsDanitzpuszta (SW Hungary). - Földtani Közlöny 151/3, 235-252.

Soós J.-NÉ 2013: Egy 19. századi mészégető kemence maradványa és ennek földtörténeti vonatkozásai Mecsekpölöskén. - e-Acta Naturalia Pannonica 5, 1-7. (24.06.2013.) ISSN 1788-9413

STRAusz L. 1923: Mecsekjánosi, Szopók és Mecsekpölöske környékének geológiája. (Über die geologischen Verhaltnisse der Gegend von Mecsekjánosi, Szopók und Mecsekpölöske (im Komitate Baranya). - Földtani Közlöny 53, 59-66, $136-138$.

Strausz, L. 1928: Das Mediterran des Mecsekgebirges in Südungarn. - Geologische und Palaeontologische Abhandlungen, N. F. 15/5, 361-418.

STRAUSz L. 1942: Adatok Baranya geológiájához. [Data on the geology of Baranya]. - Földtani Közlöny 72, $181-192$.

Szabó M., Kocsis L., Bosnakoff M. \& Sebe K. 2021: A diverse Miocene fish assemblage (Chondrichthyes and Osteichthyes) from the Pécs-Danitzpuszta sand pit (Mecsek Mts., Hungary). - Földtani Közlöny 151/4, 363-410.

Manuscript recieved: 23/03/2021 